\title{
SURFACE ELECTROMYOGRAPHY OF MASSETER AND TEMPORAL MUSCLES WITH USE PERCENTAGE WHILE CHEWING ON CANDIDATES FOR GASTROPLASTY
}

Eletromiografia de superfície de músculos masséteres e temporais com percentual de uso durante a mastigação em candidatos à gastroplastia

\author{
Andréa Cavalcante dos SANTOS, Carlos Antonio Bruno da SILVA
}

From the Núcleo do Obeso do Ceará (Ceara Obese Nucleus), Fortaleza, CE, Brazil
ABSTRACT - Background: Surface electromyography identifies changes in the electrical potential of the muscles during each contraction. The percentage of use is a way to treat values enabling comparison between groups. Aim: To analyze the electrical activity and the percentage of use of masseter and temporal muscles during chewing in candidates for gastric bypass. Methods: It was used Surface Electromyography Miotool 200,400 (Miotec ${ }^{\circledR}$, Porto Alegre/RS, Brazil) integrated with Miograph 2.0 software, involving patients between 20-40 years old. Were included data on electrical activity simultaneously and in pairs of temporal muscle groups and masseter at rest, maximum intercuspation and during the chewing of food previously classified. Results: Were enrolled 39 patients (59 women), mean age $27.1+/-5.7$. The percentage of use focused on temporal muscle, in a range of $11-20$, female literacy $(n=11 ; 47.82)$ on the left side and 15 (65.21) on the right-hand side. In the male, nine (56.25) at left and 12 (75.00) on the right-hand side. In masseter, also in the range of 11 to 20 , female literacy $(n=10 ; 43.48)$ on the left side and 11 (47.83) on the right-hand side. In the male, nine (56.25) at left and eight (50.00) on the right-hand side. Conclusion: $40-50 \%$ of the sample showed electrical activity in muscles (masseter and temporal) with variable values, and after processing into percentage value, facilitating the comparison of load of used electrical activity between the group, as well as usage percentage was obtained of muscle fibers $11-20 \%$ values involving, representing a range that is considered as a reference to the group studied. The gender was not a variable.
HEADINGS - Electromyography. Mastication. Gastroplasty. Speech, language and hearing sciences.
RESUMO: Racional: A eletromiografia de superfície identifica variações dos potenciais elétricos dos músculos durante cada contração realizada. O percentual de uso é uma forma de tratar valores possibilitando comparação entre grupos. Objetivo: Analisar a atividade elétrica e o percentual de uso dos músculos masséteres e temporais durante a mastigação em candidatos à gastroplastia. Métodos: Utilizado Eletromiógrafo de Superfície Miotool 200/400 (Miotec ${ }^{\oplus}$, Porto Alegre/RS, Brasil) integrado ao software Miograph $2.0 \mathrm{em}$ pacientes entre $20-40$ anos candidatos à gastroplastia. Foram incluídos dados relativos à atividade elétrica simultânea e em pares dos grupos musculares temporais e masséteres em repouso, máxima intercuspidação habitual e durante mastigação de alimento previamente classificado. Resultados: Foram analisados 39 pacientes ( $59 \%$ feminino), média de idade de $27,1 \pm 5,7$. O percentual de uso se concentrou em musculatura temporal, em faixa de $11-20 \%$ no sexo feminino $(n=11 ; 47,82 \%)$ referente à lateral esquerda e $15(65,21 \%)$ na lateral direita. No masculino, nove $(56,25 \%)$ na lateral esquerda e $12(75,00 \%)$ na lateral direita. Em masséteres, também na faixa de $11-20 \%$ no sexo feminino $(n=10$; $43,48 \%)$ referente à lateral esquerda e $11(47,83 \%)$ na lateral direita. No masculino, nove $(56,25 \%)$ na lateral esquerda e oito (50,00\%) na lateral direita. Conclusão: Entre $40-50 \%$ da amostra houve variação na atividade elétrica em masséteres e temporais, e, após transformação em valor percentual, facilitou-se a comparação da carga de atividade elétrica utilizada entre o grupo, bem como obteve-se percentual de uso de fibras musculares envolvendo valores de $11-20 \%$, representando uma faixa que se considera como referencial para o grupo estudado. O gênero não constituiu variável em pacientes obesos mórbidos.
DESCRITORES: Eletromiografia. Mastigação. Gastroplastia. Fonoaudiologia.

\section{INTRODUCTION}

M astication is the physiological exercise involving all senses ${ }^{22,23}$ being considered an important function of the stomatognatic system ${ }^{14}$. The structures involved in the masticatory act responsible for maintaining healthy conditions for the execution of this function, are considered fixed and mobile serving as the basis of the movements and forces involved in this context ${ }^{5}$.

The process involving the masticatory function is developed in three stages: 1) incision, where food is seized and cut in the region of incisors (phase which lasts from $5-10 \%$ of mastication), after being brought to the region premolars for 2) crunch (65-70\% of mastication) and 3) molar, spray, generating interocclusal pressure, with the milling of food during chewing stroke (25-30\% of the masticatory act)

During mastication, the muscles responsible for this function, especially the masseter, the temporal and the buccinator provides crushing force of great importance in the mastication cycles ${ }^{18,20}$ as well, it is necessary that the concentration of muscle movement is assembled in premolar and molar region ${ }^{23}$.

Several studies advocate muscle function responsible for masticatory act with the goal of efficiency for good nutrition ${ }^{3,7,23}$ and, despite considering this area of orofacial 
motricity in its relation with speech therapists in bariatric surgery team, a field new insert, contains no proof of their efficiency ${ }^{6}$, but is sought tirelessly this purpose throughout the scientific research.

Explaining a little more about the muscle function, are verifiable electric potential with current technology. According to the study, this electricity is based on the principle of cell ability to trigger electrical activity through the existence of electric potential between their plasma membranes with the presentation of electrically negative cytoplasm in relation to the extracellular ${ }^{26}$.

A muscle or muscle group to be stimulated to move in activity, there is modification of the resting potential, turning into action potential that through electromyographic reading, presents the possibility of counting increasingly objetive ${ }^{26}$.

Surface electromyography (EMG'S) is a form of measurement of the masticatory muscles functionality able to identify variations of the electric potential of the muscles during each performed contraction, supporting the development of diagnostic and therapeutic functions and orofacial motor disorders, both in chewing and swallowing. Its accuracy in the records of the electrical activity of a muscle or a muscle group is what gives this technology its applicability in bigger scale 1,2,14,21,26.

As the electromyographic signal presents great variability in comparison process to different records for the same individual or different individuals, it sought a way to compare a group of people with similarities in their sign. Normalization techniques allow comparison of electromyographic signal values, allowing the study inter individual ${ }^{1}$.

Through searching the literature, was observed the use of EMG'S in speech therapy; however, little was found specifically in the surgical treatment of obesity, where one realizes that more people are experiencing this procedure because it is something more effective maintenance of weight lost over a prolonged period ${ }^{15}$.

This study aimed to analyze the electrical activity of the masseter and temporal muscles with a percentage of use, during mastication in morbidly obese patient's candidates for gastroplasty.

\section{METHODS}

It is the study of quantitative, transversal and descriptive approach. The collection period was from October/2012 to March/2013. The project was approved by the Ethics Committe of the University of Fortaleza under No. 114,609/2012.

The subjects of the research were selected by convenience and voluntarily in the Núcleo do Obeso do Ceará, located in Fortaleza, CE, Brazil.

Were used as inclusion criteria patients aged between 20-40 years old and candidates for gastroplasty; and the exclusion of those who presented facial and/or occlusal deformity that prevented the implementation of mastication collection.

It was used for the measurements of electrical activity of the surface electromyography apparatus Miotool 200/400 (Miotec ${ }^{\circledR}$, Porto Alegre / RS, Brazil) with four channels, SDS500 sensor and integrated Miograph 2.0 software.

The technique used and the guidelines were previously explained to the patient for data collection protocols already published ${ }^{9,14,16,23,26}$. During habitual mastication, it was standardized as food, a portion of french bread $5 \mathrm{~cm}^{3}$ and signal capture time during chewing; they were analyzed in all ranges without exclusions, taking advantage of the total sample time until swallowing food. Patients underwent mastication with own cycles and spontaneous swallowing.

All EMG'S tests were performed by the same observer (SAC) and under the same environmental conditions.

Prior to each sampling site friction with non-sterile gauze soaked in $70 \%$ alcohol was performed in order to minimize artifacts $^{14}$ and improve signal capture. The reference electrode (earth) was placed in the front portion of the patient's head.

Data were obtained on the simultaneous electrical activity and pairs of temporal and masseter muscle groups during the tasks: rest, maximum clenching in maximum habitual intercuspation (MHI) and during the chewing food period.

The records were collected by $\mathrm{MHI}$ maintained for 5 seconds and repeat three times with 1 min interval addition to rest between each collection and used the average for signal normalization, equivalent to $100 \%$ of the electrical activity. The signals collected during mastication were analyzed by Root Mean Square (RMS) and expressed in microvolts (uV) 9, 14,26.

To analyze the percentage of use (PU), the following formula was used:

$$
\mathrm{PU}=\frac{\text { mastication average } \times 100}{\mathrm{MHI}}
$$

The PU is a way of normalizing the percentage of use of the muscles in activity, treated within the study group, to allow comparison of results.

\section{Statistical analysis}

In the analysis and interpretation of the data was used descriptive statistics with the use of measures of central tendency, represented by the mean, standard deviation and the maximum and minimum values. For the purposes of the calculation was used the Excel software v. 2010 (Microsoft, 2010). Elected 39 patients and planning involving the age group occurred in order to make it more concise and reduced in certain muscular condition with the goal of much more homogeneous group, as with the range of age and very real differences, disaggregates the condition comparison of muscle activity. For this fact, the increasing age influences the muscle pattern modification and aging can change aspects related to tonicity, influencing the obtained results ${ }^{21}$.

\section{RESULTS}

The group effectively studied consisted of 39 patients, 23 (59\%) women and 16 (41\%) were men with an average age for women $27.1+5.7$ years and for men, $26.1+5.2$ years.

\section{Maximum habitual intercuspation ( $\mathrm{MHI}$ )}

It was observed that the overall average of the population studied to $\mathrm{MHI}$ in temporal muscles expressed in microvolts (uV) showed 230.1 microvolts for the muscles left and 225.4 microvolts on the right. In the mean values encountered during mastication, 28.0 microvolts were observed for the left side, while the right showed 27.3 microvolts, which resulted in percentage of use of the muscle fibers with average $15.5 \%$ to the left and $14.6 \%$ right (Table 1 ).

The overall average for the $\mathrm{MHI}$ in masseter muscles expressed in microvolts, showed 157.2 microvolts to the muscles on the left and 181.6 microvolts right. The average values found during mastication were observed 22.8 microvolts to the left side, while the right showed 24.9 microvolts, which resulted in percentage of use of the muscle fibers with average $20.0 \%$ to the left and $212 \%$ right (Table 2 ).

\section{Percentage of use (PU)}

When there is the presentation of the figures for the genders in left and right temporal, proved to be average, minimum and maximum (Table 3 ), and the categorization of $\mathrm{PU}$ muscle fibers required for the exercise during mastication.

In women, the results were for the left side $47.82 \%(n=11)$ with PU between $11-20 \% ; 34.79 \%(n=9)$ between $0-10 \%$ and $17.39 \%(n=4)$ between $21-30 \%$. In the right side muscles, $65.21 \%$ $(n=15)$ with PU between $11-20 \% ; 21.74 \%(n=5)$ between $0-10 \%$ and $13.05 \%(n=3)$ between $21-30 \%$. 
TABLE 1 - Average values MHI, masticatory function and percentage of use during mastication of the left temporal muscle and right

\begin{tabular}{|c|c|c|c|c|c|c|c|}
\hline \multirow[b]{2}{*}{ Patients } & \multirow[b]{2}{*}{ Gender } & \multicolumn{2}{|c|}{$\begin{array}{c}\text { Average MHI } \\
(\mu \mathrm{V})\end{array}$} & \multicolumn{2}{|c|}{$\begin{array}{l}\text { Masticatory } \\
\text { average }(\mu \mathrm{V})\end{array}$} & \multicolumn{2}{|c|}{$\begin{array}{c}\text { Percentage of } \\
\text { use (\%) }\end{array}$} \\
\hline & & Temp. L & Temp. R & Temp. L & Temp. R & Temp. L & Temp. R \\
\hline 1 & M & 189,9 & 155,6 & 22,3 & 21,6 & 11,7 & 13,9 \\
\hline 2 & $\mathrm{~F}$ & 326,8 & 307,1 & 52,1 & 37,0 & 15,9 & 12,0 \\
\hline 3 & $\mathrm{~F}$ & 109,4 & 76,2 & 13,6 & 10,4 & 12,4 & 13,7 \\
\hline 4 & $\mathrm{~F}$ & 298,0 & 197,3 & 27,6 & 23,5 & 9,3 & 11,9 \\
\hline 5 & $\mathrm{~F}$ & 115,0 & 153,8 & 18,1 & 18,1 & 15,7 & 11,8 \\
\hline 6 & $\mathrm{~F}$ & 175,8 & 103,7 & 28,0 & 17,9 & 15,9 & 17,3 \\
\hline 7 & M & 736,7 & 781,0 & 40,9 & 47,9 & 5,6 & 6,1 \\
\hline 8 & M & 278,9 & 251,5 & 32,2 & 31,6 & 11,5 & 12,6 \\
\hline 9 & M & 128,4 & 131,1 & 16,4 & 6,9 & 12,8 & 12,9 \\
\hline 10 & $\mathrm{~F}$ & 310,3 & 350,0 & 44,3 & 48,7 & 14,3 & 13,9 \\
\hline 11 & $\mathrm{~F}$ & 138,9 & 169,1 & 27,4 & 24,3 & 19,7 & 14,4 \\
\hline 12 & $\mathrm{~F}$ & 193,5 & 151,1 & 18,4 & 16,9 & 9,5 & 11,2 \\
\hline 13 & $\mathrm{~F}$ & 186,3 & 180,1 & 39,1 & 34,0 & 21,0 & 18,9 \\
\hline 14 & M & 102,3 & 104,4 & 16,0 & 14,3 & 15,6 & 13,7 \\
\hline 15 & $\mathrm{~F}$ & 240,0 & 303,7 & 14,3 & 17,4 & 6,0 & 5,7 \\
\hline 16 & $\mathrm{M}$ & 189,2 & 299,4 & 18,8 & 25,8 & 9,9 & 8,6 \\
\hline 17 & M & 131,2 & 111,9 & 10,1 & 13,2 & 7,7 & 11,8 \\
\hline 18 & $\mathrm{M}$ & 82,2 & 74,9 & 18,6 & 13,9 & 22,6 & 18,6 \\
\hline 19 & $\mathrm{~F}$ & 47,9 & 254,3 & 16,6 & 17,5 & 6,7 & 6,9 \\
\hline 20 & $\mathrm{~F}$ & 232,9 & 218,1 & 29,4 & 27,3 & 12,6 & 12,5 \\
\hline 21 & $\mathrm{~F}$ & 578,9 & 445,0 & 45,7 & 37,9 & 7,9 & 8,5 \\
\hline 22 & $\mathrm{~F}$ & 113,2 & 93,0 & 10,2 & 10,4 & 9,0 & 11,2 \\
\hline 23 & M & 164,0 & 134,1 & 24,1 & 21,9 & 14,7 & 16,3 \\
\hline 24 & M & 215,7 & 242,9 & 16,9 & 23,8 & 7,8 & 9,8 \\
\hline 25 & $\mathrm{~F}$ & 374,1 & 469,5 & 34,2 & 33,3 & 9,1 & 7,1 \\
\hline 26 & M & 261,9 & 209,5 & 35,2 & 31,4 & 13,4 & 15,0 \\
\hline 27 & $\mathrm{M}$ & 162,5 & 162,8 & 19,2 & 22,1 & 11,8 & 13,6 \\
\hline 28 & M & 147,7 & 123,9 & 21,3 & 20,2 & 14,4 & 16,3 \\
\hline 29 & $\mathrm{~F}$ & 122,9 & 168,4 & 27,5 & 37,8 & 22,4 & 22,4 \\
\hline 30 & $\mathrm{~F}$ & 477,8 & 386,9 & 67,5 & 69,9 & 14,1 & 18,1 \\
\hline 31 & $\mathrm{~F}$ & 158,2 & 166,2 & 35,1 & 39,5 & 22,2 & 23,8 \\
\hline 32 & $\mathrm{~F}$ & 545, & 398,5 & 54,4 & 47,2 & 10,0 & 11,8 \\
\hline 33 & $\mathrm{~F}$ & 286,0 & 330,1 & 45,2 & 36,7 & 15,8 & 11,1 \\
\hline 34 & M & 21,6 & 31,2 & 21,3 & 20,3 & 98,8 & 65,1 \\
\hline 35 & $\mathrm{~F}$ & 243,5 & 276,1 & 34,0 & 24,4 & 14,0 & 8,8 \\
\hline 36 & $\mathrm{~F}$ & 118,6 & 109,6 & 27,6 & 28,4 & 23,3 & 25,9 \\
\hline 37 & $\mathrm{~F}$ & 113,0 & 170,8 & 12,9 & 18,9 & 11,4 & 11,1 \\
\hline 38 & M & 119,7 & 176,3 & 19,8 & 25,7 & 16,5 & 14,6 \\
\hline 39 & M & 337,6 & 319,9 & 35,8 & 37,0 & 10,6 & 11,6 \\
\hline
\end{tabular}

TABLE 3 - MIH values, chewing and usage percentage with differentiation between gender to temporal muscle

\begin{tabular}{|c|c|c|c|c|c|c|}
\hline Var & able & & Avg. & Min & Max & DP \\
\hline \multirow{4}{*}{$\mathrm{MHI}(\mu \mathrm{V})$} & Temporal L & Women & 248,1 & 109,4 & 578,9 & $+137,9$ \\
\hline & Temporal L & Men & 204,3 & 21,6 & 736,7 & $+162,1$ \\
\hline & Temporal $\mathrm{R}$ & Women & 238,2 & 76,2 & 469,5 & $+116,2$ \\
\hline & Temporal R & Men & 206,9 & 31,2 & 781,0 & $+172,3$ \\
\hline \multirow{4}{*}{$\begin{array}{c}\text { Mastication } \\
(\mu \mathrm{V})\end{array}$} & Temporal L & Women & 31,4 & 10,2 & 67,5 & $+15,0$ \\
\hline & Temporal L & Men & 23,1 & 10,1 & 40,9 & $+8,5$ \\
\hline & Temporal R & Women & 29,5 & 10,4 & 69,9 & $+14,1$ \\
\hline & Temporal R & Men & 24,2 & 13,2 & 47,9 & $+9,2$ \\
\hline \multirow{4}{*}{$\begin{array}{l}\text { Percentage } \\
\text { of use (\%) }\end{array}$} & Temporal L & Women & 13,8 & 6,0 & 23,3 & $+5,2$ \\
\hline & Temporal L & Men & 17,9 & 5,6 & 98,8 & $+21,9$ \\
\hline & Temporal R & Women & 13,5 & 5,7 & 25,9 & $+5,4$ \\
\hline & Temporal R & Men & 16,3 & 6,1 & 65,1 & $+13,4$ \\
\hline
\end{tabular}

In men left lateral muscles $56.25 \%(n=9)$ presented the PU between $11-20 \% ; 31.25(n=5) 0-10 \%$ and $6.25 \%(n=1)$ with PU $21-30 \%$ and $6.25 \%(n=1)$ between $91-100 \%$. In the right side muscles there was $75.00 \%(n=12)$ with PU between 11$20 \% ; 18.75 \%(n=3)$ between $0-10 \%$ and $6.25 \%(n=1)$ between $91-100 \%$.

Introducing the values for the genders in left and right masseter, proved to be average, minimum and maximum (Table 4), and the categorization of PU muscle fibers required for the exercise during the mastication.

In women the results to the left side were $43.48 \%(n=10)$ with PU between 11-20\%; 26.09\% $(n=6)$ between $21-30 \%$;
TABLE 2 - Average values MHI masticatory function and usage percentage during mastication of the left and right masseter muscles

\begin{tabular}{|c|c|c|c|c|c|c|c|}
\hline \multirow[b]{2}{*}{ Patients } & \multirow[b]{2}{*}{ Gender } & \multicolumn{2}{|c|}{$\begin{array}{c}\text { Average } \mathrm{MH} \mathrm{I} \\
(\mu \mathrm{V})\end{array}$} & \multicolumn{2}{|c|}{$\begin{array}{c}\text { Masticatory } \\
\text { Average }(\mu \mathrm{V})\end{array}$} & \multicolumn{2}{|c|}{$\begin{array}{c}\text { Percentage of } \\
\text { use (\%) }\end{array}$} \\
\hline & & Mass L & Mass $\mathrm{R}$ & Mass L & Mass $\mathrm{R}$ & Mass L & Mass $\mathrm{R}$ \\
\hline 1 & M & 83,4 & 126,0 & 15,1 & 16,3 & 18,1 & 12,9 \\
\hline 2 & $\mathrm{~F}$ & 100,9 & 94,1 & 23,2 & 25,9 & 23,0 & 27,5 \\
\hline 3 & $\mathrm{~F}$ & 30,8 & 20,9 & 10,2 & 8,5 & 33,2 & 40,6 \\
\hline 4 & $\mathrm{~F}$ & 53,4 & 107,2 & 12,0 & 16,5 & 22,5 & 15,4 \\
\hline 5 & $\mathrm{~F}$ & 41,6 & 79,5 & 11,7 & 15,1 & 28,1 & 19,0 \\
\hline 6 & $\mathrm{~F}$ & 69,8 & 54,5 & 23,8 & 21,9 & 34,1 & 40,2 \\
\hline 7 & M & 162,5 & 484,4 & 19,3 & 32,7 & 11,9 & 6,8 \\
\hline 8 & M & 130,7 & 207,2 & 26,4 & 21,4 & 20,2 & 10,3 \\
\hline 9 & M & 124,0 & 238,1 & 18,7 & 30,9 & 15,1 & 13,0 \\
\hline 10 & $\mathrm{~F}$ & 80,5 & 149,3 & 20,7 & 27,1 & 25,7 & 18,1 \\
\hline 11 & $\mathrm{~F}$ & 183,8 & 143,7 & 31,1 & 24,9 & 16,9 & 17,3 \\
\hline 12 & $\mathrm{~F}$ & 134,1 & 179,5 & 15,9 & 14,4 & 11,9 & 8,0 \\
\hline 13 & $\mathrm{~F}$ & 146,0 & 216,1 & 30,9 & 46,9 & 21,2 & 21,7 \\
\hline 14 & M & 81,6 & 109,7 & 16,6 & 21,4 & 20,3 & 19,5 \\
\hline 15 & $\mathrm{~F}$ & 228,3 & 209,7 & 15,1 & 18,2 & 6,6 & 8,7 \\
\hline 16 & $M$ & 319,6 & 335,7 & 21,3 & 22,6 & 6,7 & 6,7 \\
\hline 17 & M & 104,3 & 87,6 & 8,2 & 10,8 & 7,9 & 12,3 \\
\hline 18 & $M$ & 61,1 & 50,2 & 18,9 & 20,6 & 30,9 & 41,0 \\
\hline 19 & $\mathrm{~F}$ & 258,8 & 301,5 & 16,0 & 26,7 & 6,2 & 8,9 \\
\hline 20 & $\mathrm{~F}$ & 115,4 & 189,6 & 21,9 & 31,9 & 19,0 & 16,8 \\
\hline 21 & $\mathrm{~F}$ & 140,7 & 106,2 & 18,8 & 12,9 & 13,4 & 12,1 \\
\hline 22 & $\mathrm{~F}$ & 97,3 & 79,0 & 14,2 & 12,6 & 14,6 & 15,9 \\
\hline 23 & M & 108,3 & 39,5 & 23,6 & 11,1 & 21,8 & 28,1 \\
\hline 24 & $M$ & 135,3 & 189,7 & 13,5 & 18,4 & 10,0 & 9,7 \\
\hline 25 & $\mathrm{~F}$ & 436,8 & 400,1 & 31,0 & 30,5 & 7,1 & 7,6 \\
\hline 26 & $M$ & 204,6 & 161,3 & 31,2 & 27,8 & 15,3 & 17,2 \\
\hline 27 & $M$ & 90,0 & 153,2 & 17,5 & 22,5 & 19,5 & 14,7 \\
\hline 28 & $M$ & 148,1 & 164,6 & 24,6 & 31,2 & 16,6 & 19,0 \\
\hline 29 & $\mathrm{~F}$ & 73,2 & 122,7 & 9,9 & 20,3 & 13,5 & 16,5 \\
\hline 30 & $\mathrm{~F}$ & 231,8 & 139,5 & 47,0 & 28,3 & 20,3 & 20,3 \\
\hline 31 & $\mathrm{~F}$ & 156,0 & 168,1 & 39,5 & 37,7 & 25,3 & 22,4 \\
\hline 32 & $\mathrm{~F}$ & 528,8 & 657,3 & 48,2 & 57,2 & 9,1 & 8,7 \\
\hline 33 & $F$ & 247,7 & 240,8 & 39,2 & 35,4 & 15,8 & 14,7 \\
\hline 34 & $M$ & 28,8 & 15,0 & 19,4 & 15,0 & 67,4 & 100,0 \\
\hline 35 & $\mathrm{~F}$ & 288,3 & 327,8 & 35,3 & 34,1 & 12,2 & 10,4 \\
\hline 36 & $\mathrm{~F}$ & 26,7 & 24,5 & 21,9 & 24,2 & 82,1 & 98,8 \\
\hline 37 & $\mathrm{~F}$ & 71,7 & 92,9 & 8,4 & 13,2 & 11,7 & 14,2 \\
\hline 38 & $M$ & 253,4 & 204,9 & 32,5 & 42,4 & 12,8 & 20,7 \\
\hline 39 & $M$ & 351,4 & 411,2 & 36,4 & 43,5 & 10,4 & 10,6 \\
\hline
\end{tabular}

TABLE 4 - MIH values, chewing and usage percentage with differentiation between gender to masseter muscles

\begin{tabular}{|c|c|c|c|c|c|c|}
\hline \multicolumn{3}{|c|}{ Variable } & Avg. & Mín & Max & DP \\
\hline \multirow{4}{*}{$\mathrm{MHI}(\mu \mathrm{V})$} & Masseter L & Women & 162,7 & 26,7 & 528,8 & $+127,4$ \\
\hline & Masseter L & Men & 149,2 & 28,8 & 351,4 & $+90,8$ \\
\hline & Masseter R & Women & 178,5 & 20,9 & 657,3 & $+141,0$ \\
\hline & Masseter $\mathrm{R}$ & Men & 186,1 & 15,0 & 484,4 & $+130,7$ \\
\hline \multirow{4}{*}{$\begin{array}{l}\text { Mastication } \\
\qquad(\mu \mathrm{V})\end{array}$} & Masseter L & Women & 23,7 & 8,4 & 48,2 & $+11,9$ \\
\hline & Masseter L & Men & 21,5 & 8,2 & 36,4 & $+7,4$ \\
\hline & Masseter $\mathrm{R}$ & Women & 25,4 & 8,5 & 57,2 & $+11,7$ \\
\hline & Masseter R & Men & 24,3 & 10,8 & 43,5 & $+9,8$ \\
\hline \multirow{4}{*}{$\begin{array}{l}\text { Percentage } \\
\text { of use (\%) }\end{array}$} & Masseter L & Women & 20,6 & 6,2 & 82,1 & $+15,6$ \\
\hline & Masseter L & Men & 19,0 & 6,7 & 67,4 & $+14,3$ \\
\hline & Masseter $\mathrm{R}$ & Women & 21,0 & 7,6 & 98,8 & $+19,1$ \\
\hline & Masseter R & Men & 21,4 & 6,7 & 100,0 & $+22,7$ \\
\hline
\end{tabular}

$17.40 \%(n=4) 0-10 \% ; 8.70 \%(n=2)$ between $31-40 \%$ and $4.33 \%$ $(n=1)$ between $81-90 \%$. On the right side muscles, $47.83 \%$ $(n=11)$ with PU between $11-20 \% ; 26.09 \%(n=6) 0-10 \% ; 13.05 \%$ $(n=3)$ between $21-30 \%$ and $4.33 \%(n=1)$ between $91-100 \%$.

In men left lateral muscles were $56.25 \%(n=9)$ with PU between $11-20 \% ; 25.00 \%(n=4)$ between $0-10 \% ; 12.50 \%(n=2)$ between $21-30 \%$ and $6.25 \%(n=1)$ with PU $61-70 \%$. In the right side muscles there were $50.00 \%(n=8)$ with PU between $11-20 \%$; $31.25 \%(n=5)$ between $0-10 \% ; 6.25 \%(n=1)$ between $21-30 \%$; $6.25 \%(n=1)$ between $41-50 \%$ and $6.25 \%(n=1)$ between $91-100 \%$.

In Figures 1A and 1B, addressing the results of patients in the respective gender in their left and right temporal muscles, 
was observed linear plot, with presentation ranging from 6.1 to $22.6 \%$ for men and 5.7 to $25.9 \%$ of use for women. There was the exception in values in a single person with poor electrical muscle condition in the left temporal, $98.8 \%$ of muscle fibers to the masticatory exercise and $65.1 \%$ of them to right temporal.
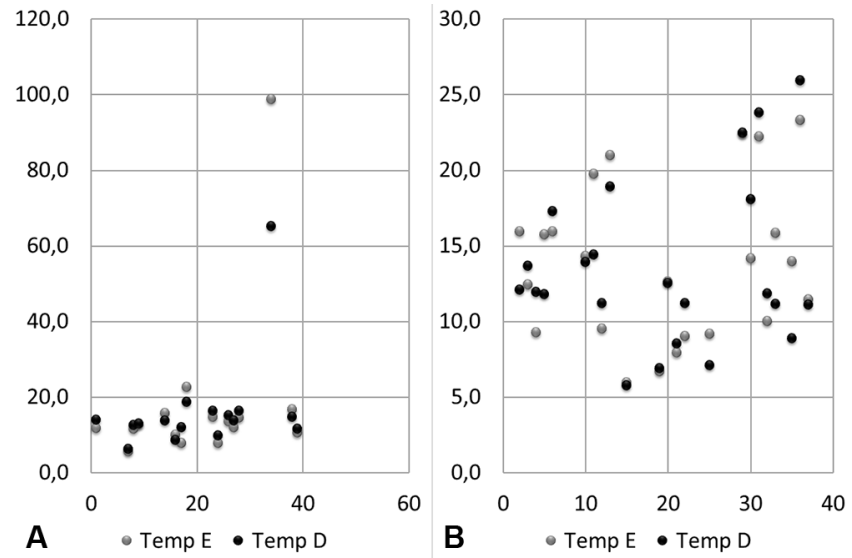

FIGURE 1 - A) Design by the use of temporal muscles of the male group; $B$ ) design by the use of temporal muscles of the female group

In Figures $2 \mathrm{~A}$ and $2 \mathrm{~B}$, addressing the results of patients in the respective gender in the left and right masseter muscles, was observed a very well defined linear line, with presentation ranging from 6.7 to $41.0 \%$ for men and 7.6 to $40.6 \%$ of use for women, but also presenting exception.

In these figures, there were also an exception in their values, coinciding with the same patient of Figure $1 \mathrm{~A}$, featuring in the left masseter the value of $67.4 \%$ and in the right, reaching $100 \%$ the use of fibers for chewing.

For women, one patient had the worst electrical muscle condition left masseter, $82.1 \%$ and right masseter, $98.8 \%$ for the same performed function.
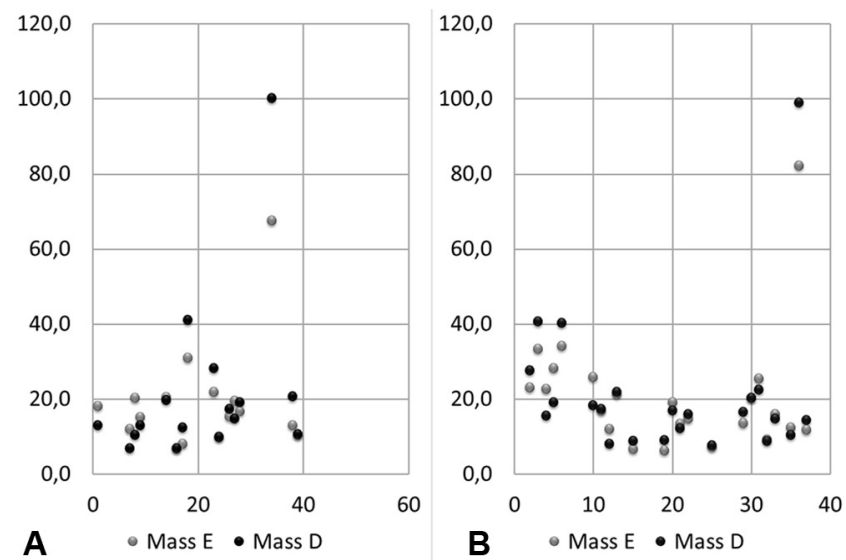

FIGURE 2 - A) Design by the use of masseter muscles of the male group; B) design by the use of masseter muscles of the female group

\section{DISCUSSION}

It is known that the electrical activity is a personal, untransferable number, represented by the value of $100 \%$ for the maximum load of each individual collection. By establishing this maximum and turn it into PU got the realization of the fact that patients, when analyzed in their use percentage for chewing, found a range of concentrations involving $11-20 \%$, a fact which allows the comparison between groups without destroying the only collected value of each individual.

On the presented results is evident the largest number of patients in electrical activity of muscle fibers in usage percentage ranging between $11-20 \%$, coinciding this value in both genders.

Researchcorroborates the idea that the averagemuscleactivity, collected by surface electromyography, increases in proportion to the resistance offered by food for mastication ${ }^{8,10,11,12,17,25}$. It was also observed that there is variation in the masseter muscle activity values according to the volume of food administered ${ }^{4}$.

Studies have reported the approach to the use of EMG'S in speech therapy in patients with dentofacial alterations that demonstrated a reduction of electric potentials during the masticatory act, reduced the maximum contraction strength and reduced performance of the muscles involved in the mastication function ${ }^{13,24}$

Study ${ }^{19}$ found that the average difference between masseter (right and left) during maximum intercuspation, was 20.0 microvolts and mastication, 10.3 microvolts.

In all these findings we looked for the existence of several studies to the measurement of electrical activity in both population without symptoms and dysfunctions such as in dental diseases; however, it did not reach any data that make correlation between morbidly obese patients and their muscular performance during mastication, as proposed in this study. One can even mention that the methods are different, making it difficult to compare results so that you can draw something around the normal or presentable in a population with morbid obesity.

These data reinforce the characterization of muscle exercise improvement for realization of mastication both the preparation and the benefit of evolution in the postoperative period of gastroplasty. The present results should open space to further studies related to the genesis, maintenance and therapy, searching for effective masticatory function, both in the surgical treatment of obesity as in maintaining the weight lost in the medium and long term.

\section{CONCLUSION}

Between $40-50 \%$ of the samples there was electrical activity in masseter and temporal muscles with variable values, and that, after transformation of this unique and intransferable value into a percentage value, facilitated the comparison of the electrical activity load used between the groups, as well as obtained percentage of use of muscle fibers involving 11-20\% values. This result is a track that can be called as a reference for the study group. Gender did not constitute variable in morbidly obese patients.

\section{REFERENCES}

1. Amorim CF. Eletromiografia de superfície (EMG). In: SALGADO, A.S.I. Eletrofisioterapia manual clínico. São Paulo: Andreoli, 2013. pp. 241-50.

2. BernardesDFF,Goffi-GomezMVS, BentoRF.Eletromiografiadesuperfície em pacientes portadores de paralisia facial periférica. Rev. CEFAC. 2010 Jan-Fev; 12(1):91-96.

3. Canterji MB, Corrêa SPM, Vargas GS, Pereira JLR, Finard SA. Intervenção fonoaudiológica na cirurgia bariátrica do idoso: relato de caso. $A B C D$, arq. bras. cir. dig.; 28 (Suppl 1): 86-87. Doi: http://dx.doi.org/10.1590/ S0102-6720201500S100023

4. Diaz-Tay J, Jayasinghe N, Lucas PW, McCallum JC, Jones JT. Association between surface electromyography of human jaw closing muscle and quantified food breakdown. Arch Oral Biol. 1991; 36 (12):893-8.

5. Douglas CR. Fisiologia aplicada à fonoaudiológica. $2^{\mathrm{a}}$. ed. Rio de Janeiro: Guanabara Koogan, 2006.

6. Gonçalves RFM, Zimberg E. Intervenção fonoaudiológica em obesos mórbidos submetidos à gastroplastia pela técnica de Fobi-Capella. $A B C D$, arq. bras. cir. digestiva.2016; 29 (1): 43-47. Doi: http://dx.doi. org/10.1590/0102-6720201600010011.

7. Gonçalves RFM, Chehter EZ. Perfil mastigatório de obesos mórbidos submetidos à gastroplastia. Rev. CEFAC, São Paulo, v.14, n. 3, junho de 2012. Doi: http://dx.doi.org/10.1590/S1516-18462011005000137.

8. Horio T, Kawamura Y. Effects of texture of food on chewing patterns in the human subject. J Oral Rehabil. 1989 Mar; 16 (2):177-83. 
9. Mangilli LD, Sassi FC, Sernik RA, Tanaka C, Andrade CRF. Caracterização eletromiográficaeultrassonográficadafunçãomastigatóriaemindivíduos com oclusão normal. J Soc Bras Fonoaudiol. 2012;24(3):211-7.

10. Mioche L, Bourdiol P, Martin JF, Noël Y. Variations in human masseter and temporalis muscle activity related to food texture during free and side-imposed mastication. Arch Oral Biol. 1999 Dec; 44(12):1005-12.

11. Mioche L, Bourdiol P, Monier S. Gum formation behavior during chewing and meatloaf with different textures. Arch Oral Biol. 2003 Mar; 48 (3):193-200.

12. Muñoz GC, Silva C, Misaki JK, Gomes ICD, Carvalho ARR. Análise dos potenciais elétricos do músculo masseter durante a mastigação de alimentos com rigidez variada. Rev. CEFAC, São Paulo, v. 6, n. 2, 127-34, abr-jun, 2004.

13. Nakata Y, Ueda HM, Kato M, Tabe H, Shikata-Wakisaka N, Matsumoto E, Koh M, Tanaka E, Tanne K. Change in stomatognathic function induced by orthognathic surgery in patients with mandibular prognathism. J Oral Maxillofac Surg. 2007;65(3):444-51.

14. Nascimento GKBO, Lima LM, Rodrigues CBS, Cunha RA, Cunha DA, Silva HJ. Verificação da força de mordida e da atividade elétrica dos músculos masseteres durante a mastigaçãoem laringectomizados totais. Rev. Bras. Odontol., Rio de Janeiro, v.68, n. 2, p. 175-9, jul/dez. 2011.

15. Christou NV, Sampalis JS, Liberman M, Look D, Auger S, McLean AP, MacLeanLD.Surgerydecreaseslong-termmortality, morbidity, and health care use in morbidly obese patients. Ann Surg. 2004 Sep;240(3):416-23. Doi 10.1097/01.sla.0000137343.63376.19.

16. Oncis MC, Freire RMAC, Marchesan IQ. Mastigação: Análise pela eletromiografia e eletrognatografia. Seu uso na clínica fonoaudiológica. Rev.Distúrbios da Comunicação, São Paulo, 18(2): 155-165, agosto, 2006.

17. Peyron MA, Lassauzay C, Woda A. Effects of increased hardness on jaw movement and muscle activity during chewing of visco-elastic model foods. Exp Brain Res. 2002 Jan; 142 (1):41-51.
18. Rahal A, GOFFI-Gomez MVS. Avaliação eletromiográfica do músculo masseter em pessoas com paralisia facial periférica de longa duração. Rev. CEFAC, São Paulo, v.9, n.2, 207-12, abr-jun, 2007.

19. RahalA,Goffi-GomezMVS. Estudoeletromiográficodomúsculomasseter durante o apertamento dentário e mastigação habitual em adultos com oclusão dentária normal. Rev Soc Bras Fonoaudiol. 2009; 14(2):160-4.

20. Rahal A, Goffi-Gomez MVS. Eletromiografia dos músculos masseteres e supra-hióideos em mulheres com oclusão normal e com má oclusão classe I de Angle durante a fase oral da deglutição. Rev. CEFAC, São Paulo, v.6, n.4, 370-5, out-dez, 2004.

21. Rahal A, Lopasso FP. Eletromiografia dos músculos masseteres e suprahióideos em mulheres com oclusão normal e com má oclusão classe I de Angle durante a fase oral da deglutição. Rev CEFAC, São Paulo, v. 6, n. 4, 370-5, out-dez, 2004.

22. Santos AC, Moura Júnior LG. Atuação fonoaudiológica na cirurgia bariátrica e metabólica. In: KLEIN D. et al. Avaliação em motricidade orofacial: discussão de casos clínicos. São José dos Campos, SP: Pulso Editorial, 2013. p.117-27.

23. Santos $A C$, Silva $C A B$. Força de mordida em pacientes candidatos à gastroplastia. ABCD, arq. bras. cir. dig. 2013; 26(4): 315-318. Doi: http:// dx.doi.org/10.1590/S0102-67202013000400012.

24. Sforza C, Peretta R, Grandi G, Ferronato G, Ferrario VF. Soft tissue facial planes and masticatory muscle function in skeletal class III patients before and after orthognatic surgery treatment. J Oral Maxillofac Surg. 2008;66(4):691-8.

25. Shiau YY, Peng CC, Hsu CW. Evaluation of biting performance with standardized test foods. J Oral Rehabil. 1999 May; 26(5):447-52.

26. Silva HJ. Protocolos de eletromiografia de superfície em fonoaudiologia. Barueri, SP: Pró-Fono, 2013. 